ISAHP 2001, Berne, Switzerland, August 2-4, 2001

\title{
A MEASUREMENT MODEL FOR ACCREDITATION PROCESS OF GRADUATE SCHOOLS IN INDONESIA WITH THE ANALYTIC HIERARCHY PROCESS
}

\author{
Yani H. Soegito and Kirti Peniwati \\ PPM Graduate School of Management \\ Jl. Menteng Raya 9, Jakarta 10340, Indonesia \\ Yh@1ppm.ac.id / Kirti@cabi.net.id
}

Keywords: accreditation process, graduate school

\begin{abstract}
Summary : Education sector in Indonesia has been facing great challenge, indicated by the country's very low position in the ranking of workforce competitiveness among nations in the world. The Department of Education has established the National Accreditation Body (abbreviated as BAN) as one of the way to improve the quality of both outcome and process of higher education in Indonesia. BAN has established a portefolio rating model, specifying eight key components, i.e., Description of the vision, mission, and objectives of the program; Program management; Curriculum and learning process; Human resource and its development; Students and their guidance; Facility and its development; Evaluation system; and Financing. BAN is committed to develop a system which shifts from a mostly input based normative evaluation system to a more descriptive system that requires self-evaluation by the administrators of each program. A rating model for graduate schools in Indonesia is proposed using the Analytic Hierarchy Process (AHP). The model uses the AHP absolute measurement approach, starting with the goal at the top level of the hierarchy and the eight components at the second level. Performance indicators for each of the eight components will be identified and located under their respected component, followed by the time frame of past performance, current activities, and future plans. A set of intensity ratings is located at the bottom of the hierarchy. While definition of intensity ratings for each indicator is instrumental in this absolute measurement system, only partial definitions can be included here.
\end{abstract}

\section{Introduction}

Education sector in Indonesia has been facing a great challenge, of which higher education in particular has been the target of heavy criticism for the poor quality of their graduates as judged by the user market. The deprived education system in Indonesia is indicated by the country's relative low position in the ranking of workforce competitiveness among nations in the world. The Department of Education of Indonesia established the National Accreditation Body (abbreviated as BAN) as a means to improve the higher education quality of both outcome and process. It is very encouraging to observe that the BAN has moved from using a mostly input based normative quantitative evaluation system to a more descriptive qualitative portefolio system. The Directorate General of Higher Education (abbreviated in Indonesian as DIKTI) has been making the effort to develop a new paradigm that is directed toward relevance, academic atmosphere, institutional management, sustainability, and efficiency (abbreviated as RAISE). This new system requires a comprehensive self assessment of a wide variety of components, each involves statement of objectives, description of actions to be done and have been done, and results to date. With this complex system, it is important to use a scientific measurement theory to ensure the accountability of the final judgment of whether or not a graduate school should be accredited or not accredited. Graduate schools were subjected to this new accreditation system for the first time, which result was just recently announced. The purpose of this paper is to propose an AHP measurement model for the accreditation process of graduate schools in Indonesia, using the key components and their descriptions that the BAN uses as the evaluation criteria. The model will be constructed using the AHP absolute measurement approach. While definition of intensity ratings for each indicator is instrumental in 
this absolute measurement system, it will not be possible to be fully done here. Hence, only partial definitions will be included in the paper. It is our intention to propose its use as a formal model for BAN. In this case, what we have here will need to be improved by collaborating with BAN officials and other education experts. It is expected that there will be significant change since BAN is in the process of evaluating its system for improvement, based on the experience of the previous implementation.

\section{The Portefolio System}

Portefolio system is an approach to obtain qualitative information used by the accreditation system that is oriented towards:

1. Quality.

2. Resource availability and its usefulness in improving learning process and student performance.

3. Aligning learning results to the vision and mission of the education institution.

4. Research and services.

5. Development of performance indicators to measure progress, both quantitative and qualitative.

6. Benchmarking to other institution, both national and international.

The portefolio system has the following characteristics:

1. It uses qualitative assessment, based on the assumption that quality assurance of a graduate program requires in-depth, comprehensive, and holistic feedback. Assessment is not a one-time picture only.

2. How well program plan is implemented and how well the components being evaluated interact with its mission and objectives determine the success of a graduate program.

3. Accreditation of a graduate program involves in-depth and overall assessment concerning the dynamics in the environment and performance of the program with its supporting resources. It also involves control and development to assure quality, efficiency, and relevance of the graduate program.

BAN has established a portefolio rating model using eight key components, i.e.: Description of the vision, mission, and objectives of the program; Program management; Curriculum and education process; Human resource and its development; Students and their guidance; Facility and its development; Evaluation system; and Financing. A graduate program needs to present its portefolio, a self-description and internal evaluation document that are subject to external evaluation and validation.

\section{The Proposed Model}

The AHP model starts with the goal at the top level of the hierarchy and the eight components of the goal (objectives) at the second level. Sub-objectives and performance indicators for each sub-objective are identified and located in the third and fourth level of the hierarchy respectively. A graduate program will be assessed on how well it strives for the objectives over time, hence time frame elements of "past performance", "present activities", and "future plans" are included and located in the fifth level. This is an absolute measurement model, so a set of intensities of "poor", "adequate", and "excellent" is located at the bottom of the hierarchy. The structure for the first five levels of the accreditation model is presented in the table below. The intensity rating elements (level 6) are not shown here. Notice that not all performance indicators can be evaluated based on the three time frames. 


\begin{tabular}{|c|c|c|c|c|}
\hline GOAL & OBJECTIVES & $\begin{array}{c}\text { SUB- } \\
\text { OBJECTIVES }\end{array}$ & $\begin{array}{l}\text { PERFORMANC } \\
\text { E INDICATORS }\end{array}$ & TIME FRAME \\
\hline \multirow{8}{*}{$\begin{array}{l}\text { Rating of } \\
\text { Graduate } \\
\text { Programs for } \\
\text { National } \\
\text { Accreditation } \\
(1.000)\end{array}$} & \multirow{8}{*}{$\begin{array}{l}\text { Description of } \\
\text { program } \\
\text { direction and } \\
\text { objectives } \\
(0.146)\end{array}$} & Identity $(0,019)$ & Completeness & \multirow{8}{*}{ Present activities } \\
\hline & & Vision $(0,029)$ & $\begin{array}{l}\text { Long-term aims } \\
\text { for excellence }\end{array}$ & \\
\hline & & Mission $(0,024)$ & $\begin{array}{l}\text { Effective guide to } \\
\text { achieve vision }\end{array}$ & \\
\hline & & Objectives $(0,042)$ & SMART & \\
\hline & & $\begin{array}{l}\text { Characteristic of } \\
\text { graduates }(0,012)\end{array}$ & & \\
\hline & & \multirow[t]{3}{*}{ Standards $(0,028)$} & Input & \\
\hline & & & Process & \\
\hline & & & Environment & \\
\hline & \multirow{20}{*}{$\begin{array}{l}\text { Management of } \\
\text { the program } \\
(0.133)\end{array}$} & \multirow{5}{*}{$\begin{array}{l}\text { Written guidelines } \\
\text { for program } \\
\text { management } \\
(0.028)\end{array}$} & $\begin{array}{l}\text { Curriculum and } \\
\text { teaching method }\end{array}$ & \multirow{20}{*}{$\begin{array}{l}\begin{array}{l}\text { Past } \\
\text { performance }\end{array} \\
\text { Present activities } \\
\text { Future plan }\end{array}$} \\
\hline & & & Management staff & \\
\hline & & & $\begin{array}{l}\text { Student } \\
\text { administration }\end{array}$ & \\
\hline & & & $\begin{array}{l}\text { Equipment's and } \\
\text { facilities }\end{array}$ & \\
\hline & & & Funding & \\
\hline & & \multirow[t]{6}{*}{$\begin{array}{l}\text { Organization } \\
\text { policy }(0.024)\end{array}$} & $\begin{array}{l}\text { Requirements for } \\
\text { enrolment }\end{array}$ & \\
\hline & & & Academic calendar & \\
\hline & & & Rules of conduct & \\
\hline & & & $\begin{array}{l}\text { Evaluation, } \\
\text { Requirements for } \\
\text { graduation }\end{array}$ & \\
\hline & & & $\begin{array}{l}\text { Faculty and } \\
\text { facility }\end{array}$ & \\
\hline & & & Education fee & \\
\hline & & \multirow{2}{*}{$\begin{array}{l}\text { Organization } \\
\text { structure }(0,015)\end{array}$} & Institution & \\
\hline & & & Program of study & \\
\hline & & \multirow{2}{*}{$\begin{array}{l}\text { Human resource } \\
\text { capability }(0,025)\end{array}$} & Competence & \\
\hline & & & Commitment & \\
\hline & & \multirow{2}{*}{$\begin{array}{l}\text { Program } \\
\text { development plan } \\
(0,021)\end{array}$} & $\begin{array}{l}\text { Use of past } \\
\text { experience }\end{array}$ & \\
\hline & & & $\begin{array}{l}\text { Reference to } \\
\text { vision and } \\
\text { objectives }\end{array}$ & \\
\hline & & \multirow{3}{*}{$\begin{array}{l}\text { Management } \\
\text { Report }(0,020)\end{array}$} & Accuracy & \\
\hline & & & Completeness & \\
\hline & & & Follow up control & \\
\hline & \multirow{5}{*}{$\begin{array}{l}\text { Curriculum and } \\
\text { learning process } \\
(0.160)\end{array}$} & \multirow{4}{*}{$\begin{array}{l}\text { Research or } \\
\text { professional } \\
\text { activities }(0,040)\end{array}$} & Type of activities & \multirow[b]{5}{*}{ Past } \\
\hline & & & Manpower support & \\
\hline & & & Financial support & \\
\hline & & & Facility support & \\
\hline & & & Broad & \\
\hline
\end{tabular}




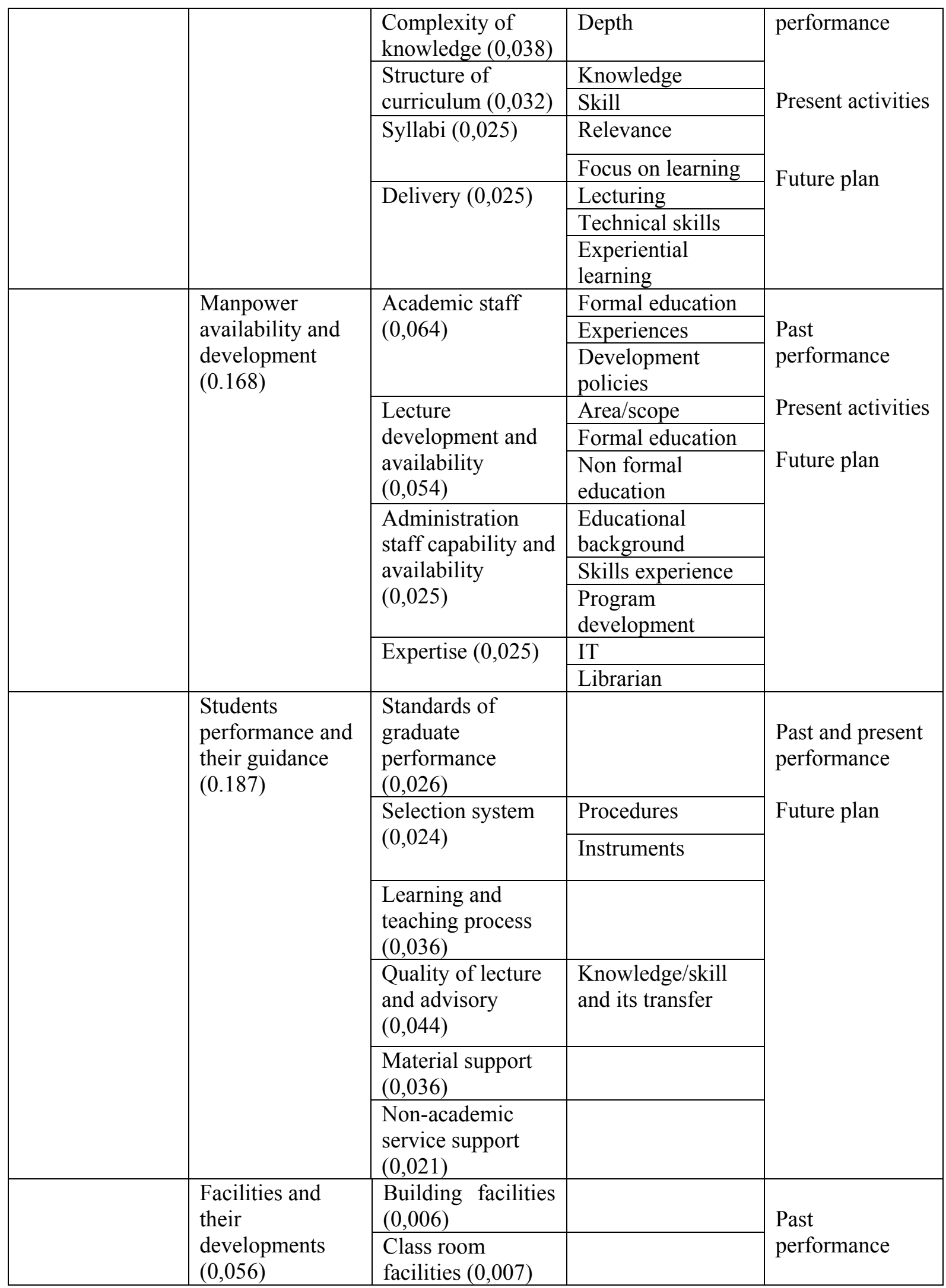




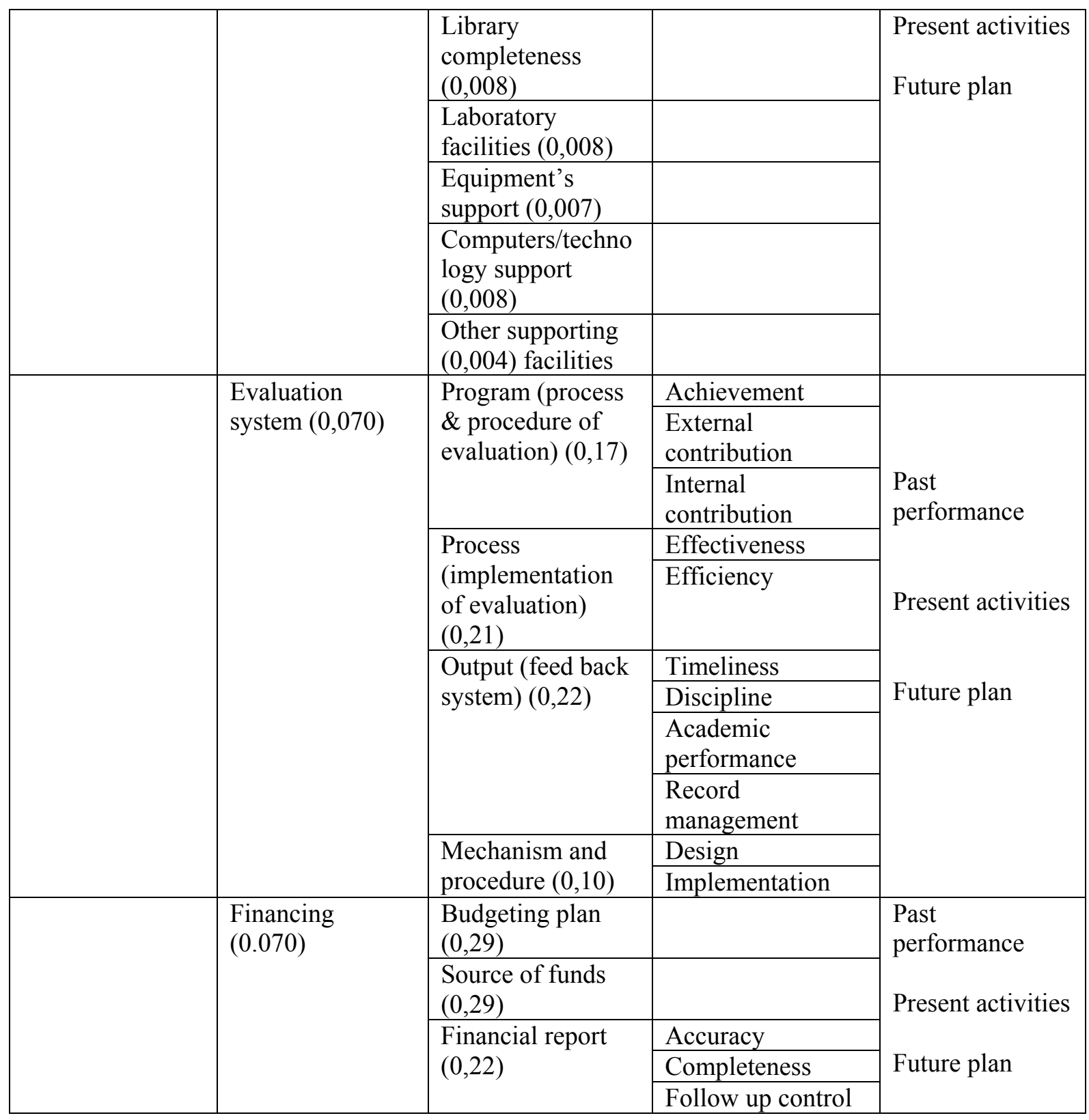

\section{Definition of Intensity Ratings}

The set of intensity ratings of "poor", "adequate", and "excellent" located at the bottom of the hierarchy must be defined to reduce the subjectivity of the judgments. The following is an example of the definition for the intensities to judge the quality of the sub-objective of Academic Lecturing and Advisory to achieve the goal of Student Performance and Their Guidance. This is selected because it is the most important objective and subobjective. Notice that there are only two time frames used. 


\begin{tabular}{|c|c|c|c|}
\hline SUB - OBJECTIVES & $\begin{array}{c}\text { TIME } \\
\text { FRAME }\end{array}$ & $\begin{array}{l}\text { INTENSITY } \\
\text { RATING }\end{array}$ & DEFINITION \\
\hline \multirow[t]{6}{*}{$\begin{array}{l}\text { Quality of lecture and } \\
\text { advisory }\end{array}$} & \multirow[t]{3}{*}{$\begin{array}{l}\text { Past and } \\
\text { present } \\
\text { performance }\end{array}$} & Poor & $\begin{array}{l}\text { - No feedback system or } \\
\text { - On the average, the majority } \\
\text { of students stated that they } \\
\text { are not satisfied with the } \\
\text { quality of faculty members' } \\
\text { knowledge and ability to } \\
\text { deliver. }\end{array}$ \\
\hline & & Adequate & $\begin{array}{l}\text { On the average, the majority } \\
\text { of students stated that they are } \\
\text { satisfied with the quality of } \\
\text { faculty members' knowledge } \\
\text { but not on their ability to } \\
\text { deliver. }\end{array}$ \\
\hline & & Excellent & $\begin{array}{l}\text { On the average, the majority } \\
\text { of students are satisfied with } \\
\text { both the qualities of faculty } \\
\text { members' knowledge and } \\
\text { their ability to deliver. }\end{array}$ \\
\hline & \multirow[t]{3}{*}{ Future plans } & Poor & $\begin{array}{l}\text { No plan to improve quality of } \\
\text { lecture and advisory. }\end{array}$ \\
\hline & & Adequate & $\begin{array}{l}\text { There is a plan to improve } \\
\text { quality of lecture and } \\
\text { advisory, but not part of } \\
\text { strategic plan. }\end{array}$ \\
\hline & & Excellent & $\begin{array}{l}\text { There is a plan to improve } \\
\text { quality of lecture and advisory } \\
\text { as part of strategic plan. } \\
\text { Current activities indicate } \\
\text { implementation of the plan. }\end{array}$ \\
\hline
\end{tabular}

\section{Evaluation Process}

Assessment for accreditation begins with a participating Graduate School submits its Portefolio report to the BAN. The report must include all the proof documents in detail and an executive summary. The practice of BAN at the moment is to allow participants to add materials during their preliminary evaluation. A small team consists of qualified representatives from leading graduate schools evaluates the report and provide initial judgment regarding the accreditation score of the school.

Without this AHP measurement system, the result of team evaluation would be highly subjective. We propose that BAN would allow the participating schools to submit their portefolio with their self-assessment presented using the model. The small team should present their preliminary result in the form of a set of rating judgments regarding each and every performance indicator. The AHP model would provide preliminary synthesized score for each school. At this stage, the team would also indicate any indicator that requires clarification or proof. This means that the rating provided would be subject to revision after the next stage of visitation.

The small team of BAN would visit the graduate school for clarification and confirmation of the preliminary result. This opportunity has been used by the team to communicate with faculty members and students for their direct information from their parts. The team would then revise their judgments based on the result of the visit, 
and the AHP model would again, synthesize the judgments and provide new scores. This should be the final accreditation score for the schools, with its corresponding classification of the accreditation status.

\section{Requirement for Improvement and Follow up by BAN}

The model proposed here needs to be revised and officially approved by BAN. Although BAN is an independent institution, it may want to refer to relevant government regulations. BAN would also need to set a standard for classifying schools based on the scores as "Excellent", "Learning", or "Not Accredited". One needs to keep in mind that this model only concerns with the quality of graduate schools, regardless of the discipline. This means that another assessment system is required, developed from the perspective of each discipline. This needs to be done by the respective academic or professional associations.

\section{References}

Badan Akreditasi Nasional Perguruan Tinggi, Departemen Pendidikan Nasional (1999). Workshop materials for Portefolio preparation for post-graduate programs.

Eyrich, H.G., (1991), Benchmarking to Become the Best of Breed, Manufacturing Systems, April 1991, Hitchcock Publishing Company.

Peniwati, K. (2000), The Analytic Hierarchy Process: Its Basics and Advancements, Proceedings of the Indonesian Symposium on the Analytic Hierarchy Process, PPM Institute of Management, Jakarta.

Saaty, T.L. (1999), Decision Making for Leaders, 3rd edition, RWS Publication, Pittsburgh. 
